\title{
REALISMO Y ANTIRREALISMO EN LA CONCEPCIÓN SEMÁNTICA DE LAS TEORİAS CIENTÍFICAS *
}

LEON OLIVE

Instituto de Investigaciones Filosóficas, UNAM

En una discusión reciente ${ }^{1}$ Bas van Fraassen, uno de los más destacados defensores de la concepción semántica de las teorías científicas, sostuvo que éstas, si bien pueden identificarse a través de sus modelos, no pueden identificarse con sus modelos.

En esta ocasión discutiré esta afirmación para elucidar lo que a mi juicio es todavía una confusión en el uso de las nociones de modelo, que ha estado presente en otros trabajos de van Fraassen y que se encuentra también en las concepciones de Pérez Ransanz. ${ }^{2}$

Recordaré muy brevemente que uno de los más importantes avances en las concepciones recientes sobre las teorías científicas consiste en desechar la idea de que éstas están formadas sólo por conjuntos de enunciados. Desde diferentes perspectivas se ha ido logrando un consenso en el sentido de que las teorías están formadas de modo principal por modelos. Pero esto no significa un gran avance mientras no haya claridad en lo que se entiende por modelo, ya que esta noción es una de las más ambiguas que puede haber en la filosofía de la ciencia. Además, es necesario aclarar cuáles tipos de modelo forman parte, o incluso constituyen la identidad de una teoría, si es que lo hacen, y cómo lo hacen.

* Agradezco a Ana Rosa Pérez Ransanz sus comentarios críticos a una versión previa de este trabajo.

1 VI Simposio Internacional de Filosofía, IIF-UNAM, Agosto 1985.

2 Pérez Ransanz [1985]: "El concepto de teoría empírica según van Fraassen"; y van Fraassen [1985]: "Sobre la cuestión de la identificación de una teoría cientifica (réplica a Pérez Ransanz)", ambas en Critica, Revista Hispanoamericana de Filosofía, No. 5l, diciembre 1985. Citadas de aquí en ade. lante como [1985]. 
Para los fines que aquí nos interesan es pertinente recordar tres sentidos que tiene la noción de modelo:

1) modelo en el sentido de satisfacción de enunciados de un lenguaje formal por una interpretación que los haga verdaderos; por comodidad me referiré a éstos como modelos lógicos;

2) modelos enunciativos, y

3) modelos icónicos. ${ }^{3}$

Basándome en las ideas de Harré para 2) y 3), pero introduciendo algunas modificaciones que me parecen importantes, propongo entender los modelos enunciativos y los icónicos de la siguiente manera:

2) Si $\mathrm{T}$ y $\mathrm{T}^{\prime}$ son dos conjuntos de enunciados, entonces $\mathbf{T}^{\prime}$ es un modelo enunciativo de $\mathrm{T}$ si y sólo si para todo $p$ en $\mathrm{T}$ existe un $q$ en $\mathrm{T}^{\prime}$ tal que si $q$ es aceptable para una comunidad epistémica, esto es, si $q$ es objetivo, se presume que $p$ es verdadero, es decir, aceptable para todo sujeto racional posible. ${ }^{4}$

3) M es un modelo icónico de $\mathrm{N}$, si y sólo si es posible construir dos conjuntos de enunciados $\mathrm{T}^{\prime}$ y $\mathrm{T}^{\prime}$ tales que 'T describe $\mathrm{M}, \mathrm{T}^{\prime}$ describe $\mathrm{N}$ y $\mathrm{T}^{\prime}$ 'es un modelo enunciativo de T. M y $\mathbf{N}$ son objetos de la experiencia u objetos abstractos.

En adelante, por comodidad, me referiré a cada uno de los anteriores como modelos 1 , modelos 2 y modelos 3 , respectivamente.

3 Cf. Harré [1970]:The Principles of Scientific Thinking, University of Chicago Press, cap. 2, para un desarrollo de las nociones 2) y 3).

- Para una elucidación de estas ideas de objetividad y verdad, véase Olivé (inédito), "Dos concepciones de la verdad y sus relaciones con teoría social", y también Olivé [1984 b], "Villoro: sobre objetividad, verdad y saber", en Critica, Revista Hispanoamericana de Filosofía, No. 48, diciembre 1984. 
Es importante aclarar que una misma estructura abstracta puede jugar el papel de modelo lógico o el de modelo icónico. Las elucidaciones anteriores, pues, deben verse como aclaraciones de los sentidos en los que puede usarse el término 'modelo', no como definiciones de estructuras. Una misma estructura, entonces, vista desde la perspectiva de la satisfacción de ciertas condiciones de definición, juega el papel de un modelo lógico. Pero la misma estructura, vista desde la perspectiva de su capacidad de representación de otro objeto, empírico o abstracto, desempeña el papel de modelo icónico. La diferencia no radica en su identidad, sino en la función sobre la cual se ponga énfasis.

Las concepciones acerca de la estructura de las teorías científicas que han cobrado vigor recientemente y que han hecho hincapié en que aquéllas están formadas por modelos, no siempre aclaran el sentido en el que utilizan el término de modelo, pero muchas veces queda también confusa su idea acerca de cuál es el papel que necesariamente deben jugar los modelos como partes constitutivas de las teorías científicas.

La falta de una distinción clara en este sentido, por ejemplo, ha hecho que defensores de la concepción semántica de las teorías, como van Fraassen, pudieran aparentemente sostener una posición antirrealista. Esto, sin embargo, a costa de la claridad sobre lo que efectivamente está involucrado en la aseveración y aceptación de una teoría científica. Las presiones que Ana Rosa Pérez Ransanz ejerció sobre van Fraassen en la confrontación reciente a la que aludí antes, lo llevaron a explicitar los compromisos que se asumen por la aseveración y aceptación de una teoría científica, los cuales son inseparables de su concepción de la estructura de las teorías.

Veremos que al poner en claro esos compromisos, van Fraassen acepta de hecho una posición realista, y no puede 
menos que aceptarla bajo pena de incoherencia. Esto nos permitirá apreciar no sólo una interesante concepción de lo que está en juego en la estructura y por consiguiente en la aceptación de una teoría científica, sino también ofrecer apoyo para la tesis de que las concepciones acerca de la estructura de las teorías no son inocentes ni neutrales con respecto a compromisos sobre la relación de ellas mismas con el mundo que pretenden describir, es decir, no son neutrales con respecto a problemas epistemológicos $\mathrm{y}$, más aún, no lo son con respecto a problemas ontológicos.

Según van Fraassen "presentar una teoría es especificar una familia de estructuras, sus modelos; y en segundo lugar, especificar ciertas partes de esos modelos... como candidatos para la representación directa de fenómenos obser. vables." ${ }^{5}$

En su réplica a Pérez Ransanz, van Fraassen confesó que lasta entonces no había puesto suficiente cuidado acerca de cómo conciliar dos maneras en las que típicamente había estado hablando de las teorías científicas: "Por una parte afirmo que las teorías dicen algo acerca de cómo es el mundo; y por otra parte, sostengo que exponer una teoría es exponer una clase de modelos. ¿Cómo pueden ser correctas ambas cosas?" [1985].

Siguiendo a Giere, van Fraassen habla por un lado de una "definición teórica (de una clase de sistemas)", es decir, con esto se describe la clase de modelos de la teoría, los que constituyen la teoría; y por otra parte habla de la “hopótesis teórica (la proposición de que ciertas entidades reales en el mundo pertenecen a esta clase de sistemas, o la proposición más débil de que son aproximadamente los mismos que ciertos miembros de esta clase)" [1985].

Me interesa mucho destacar la preocupación de van Fraassen en el sentido de que "una teoría debe ser de tal

5 The Scientific Image [1980], Oxford University Press, p. 64. 
índole que pueda ser verdadera o falsa, es decir, debe tener sentido preguntar si es verdadera o es falsa" [1985]. Las teorías, pues, no son sólo clases de modelos, sino que incluyen algo más: "una proposición que relaciona esta clase de modelos con la realidad" [1985].

Van Fraassen sostiene que si se presentan los modelos de cierta manera adecuada, entonces es posible tener una proposición teórica general del estilo de "el mundo es una de estas estructuras", es decir, uno de los modelos de la teoría. Pero si no se impone ninguna restricción a lo que la clase de modelos pueda ser, entonces no puede sostenerse que la clase de modelos determina la proposición teórica. Particularmente, sin ninguna restricción sobre lo que la clase de modelos pueda ser, no puede sostenerse que la proposición teórica tiene la forma general "el mundo real es uno de estos modelos" [1985]. La manera que propone de especificar los modelos (definición teórica) es que

una estructura pertenece a la clase $E$ si y sólo si sus elementos son tales que se cumple $A_{1}, \ldots, A_{n} \ldots$

ahora la aseveración teórica podría ser simplemente que el mundo es una de esas estructuras [de tipo $E$ ] [1985].

¿Qué se está diciendo con esta aseveración teórica? En mi opinión, que existe una estructura, $e$, la cual pertenece a la clase $E$; pero además hay la pretensión de que la estructura $e$ es isomorfa a una parte del niundo empírico, es decir, juega el papel de un modelo icónico adecuado con respecto a una parte del mundo; y finalmente, queda implícito que existe una descripción de la estructura $e$, la cual juega el papel de modelo enunciativo con respecto a una cierta descripción de esa parte del mundo.

Van Fraassen, entonces, ha aceptado un esquema del siguiente estilo: 


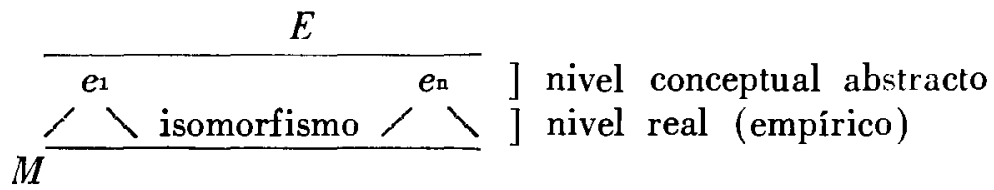

$M$ es el mundo empírico, el cual para van Fraassen es independiente de los marcos conceptuales y de los modelos bajo los cuales se interpreta ese mundo. El reconocimiento de la existencia independiente del mundo accesible a la experiencia, con respecto a los marcos conceptuales, y la idea de que las teorías están formadas por modelos que juegan un papel icónico, es el elemento realista que ahora ha emergido con toda claridad en la concepción de van Fraassen (véase van Fraassen [1985]).

Aclarada esta situación, quiero ahora pasar a la concepción de Pérez Ransanz, en particular acerca de cómo entiende ella los modelos y su papel de elementos constitutivos de las teorías. Sugeriré especialmente que hay una confusión en su concepción de modelo cuando se relaciona con la aplicación de una teoría.

El problema surge, a mi modo de ver, porque Pérez Ransanz enfatiza el papel lógico de los modelos que son constitutivos de las teorías. Esto es, acepta con van Fraassen y con la concepción estructural que una manera adecuada - para ella quizá la mejor- de formular una teoría es a través de la presentación de condiciones de definición. $\mathrm{Al}$ pensar de esta manera la formulación de las teorías, Pérez Ransanz efectivamente subraya el papel lógico de los modelos. El papel icónico que deben desempeñar me parece que queda sólo de modo implícito en la concepción de aplicación que suscribe, pero es aquí donde sobresale lo que en mi opinión es una confusión.

Desde mi punto de vista, una teoría empírica tiene la pretensión de aplicarse al mundo empírico. En este sentido la aplicación de una teoría debe ser una parte del mundo 
empírico. Pero dicha aplicación se consigue a través de la construcción de modelos, los cuales son fundamentalmente entidades abstractas. Pérez Ransanz pierde de vista que el proponer y aceptar una teoría empírica es decir que hay un isomorfismo entre una parte del mundo y un modelos icónico, el cual puede ser descrito a través de un modeloz enunciativo, y que también puede ser un modelo1 si se formula un conjunto de condiciones de definición que son satisfechas por esta estructura que es el modelo. Esta dificultad se aprecia en aseveraciones de Pérez Ransanz del siguiente estilo: "los sistemas empíricos que supuestamente explica una teoría son idealizaciones de los fenómenos empíricos"; o bien en relación con las aplicaciones, cuando afirma: "por mi parte creo que las aplicaciones intencionales deben verse como partes de la teoria. Pero las aplicaciones intencionales deben distinguirse de los fenómenos mismos y de los sistemas empíricos". Pero, ¿cómo hacer esa distinción si a la vez, como señalé antes, los sistemas empíricos son vistos como idealizaciones? Creo que la falta de un reconocimiento explícito del papel que juegan las estructuras como modelos teóricos es lo que ha obstaculizado aclarar lo que está en juego en esta dificultad. ${ }^{6}$

Finalmente, quiero referirme a una de los preocupaciones centrales de Pérez Ransanz, a saber, la de elucidar la concepción de la base y el proceso de contrastación de las teorías, de modo compatible con una concepción modeloteórica. Aun cuando reconoce que las teorías están formadas -quizá entre otras cosas- por estructuras que desempeñan papeles de modelos lógicos y de modelos icónicos, según lo que ha expresado en el trabajo citado [1985], las aplicaciones, como idealizaciones de sistemas empíricos, son también modelos icónicos. Si la base de contrastación está for-

6 Véase Olivé [1984 a]: "Sobre el realismo convergente", Crítica, Revista Hispanoamericana de Filosofía, No. 48, diciembre 1984. 
mada por aplicaciones, y éstas a la vez se ven como parte constitutiva de la teoría, entonces no queda más que contrastar a la teoría con partes constitutivas de ella misma.

Es preciso distinguir entre el hecho de que la delimitación del campo de aplicación y del de contrastación de una teoría no pueda identificarse con independencia de la teoría, del hecho de que esa base de contrastación y las aplicaciones de la teoría sean partes constitutivas de la misma. Por mi parte considero que la base de contrastación, y a lo que se aplica una teoría, es una parte del mundo empírico. Esto no pertenece a la teoría. Pero para contrastar y aplicar una teoría es preciso que haya una estructura abstracta, un modelo, que pretende ser isomorfo a una parte del mundo. Éste es el que sí forma parte de la teoría. Creo que Pérez Ransanz todavía nos debe una clarificación de qué son las aplicaciones de una teoría y cómo se relacionan tanto con los modelos de la misma como con los fenómenos de los cuales trata.

El paso a una concepción modelo-teórica abre un importante campo de investigación sobre las teorías científicas, pero esto sólo podrá ser explorado fructíferamente en la medida en que se reconozca el factor realista, inevitable, que ha aflorado con la aclaración que nos ha hecho van Fraassen: el mundo empírico sobre el cual pretenden aplicarse las teorías, si bien debe ser identificado a través de ellas, no depende existencialmente de ellas. 


\section{SUMMARY}

Bas van Fraassen, one of the most energetic defenders of the semantic conception of scientific theories, has recently held that while scientific theories can be identified through their models they cannot be identified with them (van Fraassen [1985], cf. this volume). In this paper I want to discuss the content and implications of this idea. I hold that it reveals a confusion present in some of van Fraassen's previous works, and also that it now shows a commitment to a view compatible with a form of realism. I go on to argue that the confusion at issue is also present in Pérez Ransanz's conception of scientific theories, according to what she expressed in her debate with van Fraassen.

I stress the idea that there are at least three ways in which the notion of "model" can be used, which are relevant in philosophy of science for the analysis of the structure and function of scientific theories:

1) model in the sense of a structure that satisfies a set of conditons of definition; I refer to this type as logical models;

2) sentential models; and

3) iconic models.

For types 2) and 3) I follow Harré [1970] with some modifi. cations which I consider adequate for the analysis of science I wish to defend:

Sentential Models. Let T and ' $\mathrm{T}^{\prime}$ be two sets of sentences; $\mathrm{T}^{\prime}$ is a sentential model of $T$ if and only if for every $p$ in $T$ there is a $q$ in $T^{\prime}$ such that if $q$ is acceptable for an epistemic community, i.e. $q$ is objective, then $\mathrm{p}$ is supposed to be true, i.e. acceptable for any rational being. (Cf. Olivé [unpublished] for an explication of the notions of objectivity and truth here assumed.)

Iconic Models. $\mathrm{M}$ is an iconic model of $\mathrm{N}$, if and only if it is possible to construct two sets of sentences, $\mathrm{T}^{\prime}$ and $\mathrm{T}$, such that $\mathrm{T}^{\prime}$ describes $M, T$ describes $N$ and $T^{\prime}$ is a sentential model of T. $M$ and $\mathrm{N}$ are either abstract objects or objects of possible experience.

Thus the same structure can play the role of a logical model or of an iconic model. The very same structure, from the perspective of satisfaction of certain conditions of definition plays the role of a logical model. But seen from the perspective of its capacity to represent another object, it plays the role of an iconic model. 
Van Fraassen's recent declarations have made explicit that he considers theories as constituted by structures which certainly play the role of both logical and iconic models. In this sense he adopts as a matter of fact a realist position, namely that there is an empirical world which is independent of the theories and conceptual frameworks used to conceptualize it, and also that theories are constituted by structures that play the role of iconic models.

I further contend that Pérez Ransanz unduly stresses the logical role of models and overlooks their iconic role. This arises out of her emphasis in that scientific theories must be seen as sets of structures that satisfy certain conditions of definition, and also from her idea that intended applications of theories must be seen as parts of the very same theories.

From my own point of view, an empirical theory has built into itself the claim that it can he applied to the empirical world. In this sense applications must be seen as part of the empirical world, not as parts of theories. It is true, however, that such applications involve first of all the construction of models, which are abstract entities. Finally, I discuss Pérez Ransanz's ideas as to the empirical basis for theory testing. The problem is that she regards applications as idealizations of empirical systems, thus as models, and hence as parts of theories. So, if the empirical basis is constituted by applications, but in turn these are seen as parts of theories, she is committed to the view that theories must be tested against structures which are constitutive parts of themselves. 